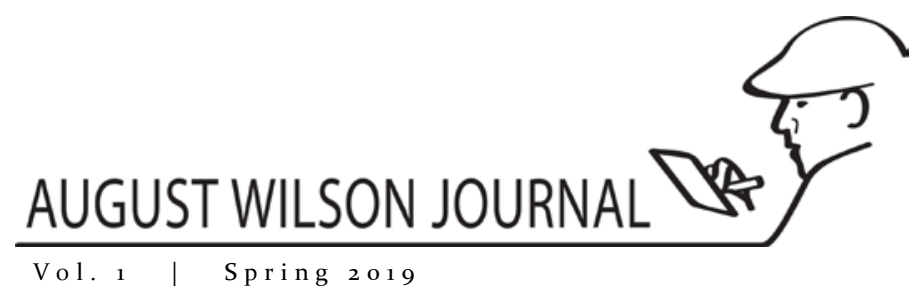

\title{
Reading August Wilson's Character and His Characters: A Suggestive Introduction
}

\author{
By Alan Nadel \\ William T. Bryan Chair in American Literature and Culture at the University of Kentucky
}

By maintaining staunchly that he not enable others to take away what was rightfully his, Wilson, whether rich or poor, was honoring the spirit of his mother, Daisy Wilson.

- Alan Nadel

\begin{abstract}
In this short piece, Nadel argues that is it crucial for Wilson's characters, like Wilson himself, to control the terms and conditions of their existence.

\author{
Keywords \\ August Wilson, Alan Nadel, American Century Cycle, O'Neill Center, Daisy Wilson
}

If the ten plays in August Wilson's American Century Cycle are not historical dramas, that is, plays based on historical events and figures, they are nevertheless historical context, in that they give cultural dynamics of African American life specific to each decade of the century cogent dramatization. Similarly, although none of Wilson's plays is autobiographical, they understandably draw on the array of warriors, entrepreneurs, hustlers, accommodators, madmen, and shamans who infused Wilson's life. In this context, I believe, briefly considering an aspect of Wilson's his personal ethos, his character, provides an apt and paradigmatic introduction to the historicity of his characters.

In 1982, when Ma Rainey's Black Bottom won the national competition that entailed its being workshopped at the O'Neill Center, Wilson, at the time working as a cook for $\$ 84$ a week, was offered a $\$ 25,000$ advance to stage the play on Broadway. When he read the contract, however, he discovered it required his ceding artistic control; the producers could bring in additional authors and to turn the play into a musical. When he called the producer, he was told, "in this business we go a lot on faith; just sign the contract and we'll work out the details

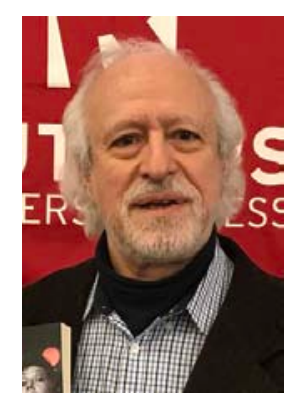

Alan Nadel later," to which Wilson responded, "as long as the words don't mean what they say, why not write the contract my way." Not surprisingly, he did not sign the contract and instead accepted Lloyd Richards's offer to put on the play at the Yale Repertory.

More than a decade later, after Ma Rainey had had a successfully Broadway run on Wilson's terms, as did four more of his plays, after he had won numerous prizes (including two Pulitzer Prizes and six Drama Critics Circle Awards, and after Fences had become the 
most lucrative drama in the history of American theater, Wilson was still in prolonged negotiations with Hollywood over the screen adaptation of Fences. In the late 1990s, he told me that it was Hollywood's way to fly you out there, put you up at the Ritz Carleton, chauffer you around in luxurious limos, and shower you with expensive meals and drinks, "then they start to take it away, and they've got you." Wilson's response was to refuse the Ritz Carlton in favor a motel and shun the limo in favor of a taxi. "It makes them crazy," Wilson told me. "They don't know what do with me."

By maintaining staunchly that he not enable others to take away what was rightfully his, Wilson, whether rich or poor, was honoring the spirit of his mother, Daisy Wilson. When he was a child, she won a new washing machine in a radio phone-in contest, but the station, upon discovering she was black, instead gave her a Salvation Army coupon for used washer. Even though Daisy at the time was doing laundry for a family of six by hand, she refused to accept the used washer instead of the one she had rightfully won but would never receive.

Both of these stories from Wilson's biography echo of Troy Maxson's refusal to allow Cory to play football, because, he believed, sports opportunities (like Hollywood luxuries) were things that could be taken away by white industry and media. Yet Troy's attitude also indicates the intersection of Wilson's character with the historicity of his characters. When those characters assert unflinching control over what is theirs, they reveal the internalized historical legacy that informs the $20^{\text {th }}$-century cycle, because the right to control property distinguishes humans from objects: you can own your dog, but your dog cannot own you. (BTW: This principle does not apply to cats.) Hence, taking away something that belongs to a person disavows his or her humanity in favor of another person's more privileged property rights. This form of disavowal-whether it entails material goods, a proper name, or the capacity to bear witness - was inherent to slavery, foundational to Jim Crow, and intrinsic to a plethora of racialized practices throughout the $2 \mathrm{o}^{\text {th }}$ century.

From this perspective, in Two Trains Running, Hambone's relentless demand for his ham, like Ma Rainey's persistent control over the conditions by which her voice may be commodified, or, in The Piano Lesson, Boy Charles's dying to reclaim the piano for which his grandmother was traded reflect not just Wilson's character but the myriad historical struggles that conditioned his characters. Aunt Ester's bill of sale, as she points out in Gem of the Ocean, is worthless, but the fact that she possesses it is invaluable in the same way that, in Jitney, the jitney drivers' right to control the terms and conditions of their rides is crucial to their identity. Wilson's cycle and his century concludes in 1997, when Harmond, in Radio Golf, forfeits a promising political career to subordinate his personal aspirations to Old Joe's rightful ownership of Aunt Ester's house.

The triumph of capitalism, we must remember, originated not in the protection of property rights from royal fiat, but from the inclusion of human flesh with the realm of property. The surplus capital that the Industrial Revolution's textile industry produced supported investment in a broad spectrum of imperial endeavors, including, but not limited to, the harvesting and commodification of Africans and their labor. That capital vitalized shipping, railroads, banks, and factories of every sort, in both slave-holding and nonslaveholding parts of the globe, all benefitting, directly or indirectly, form the cheap cotton that slavery made possible, out of which affordable textiles and immense profits were made.

Near the end of Fences, Troy Maxson speaks directly to Death:

I'm gonna take and build me a fence around this yard. See? I'm gonna build me a fence around what belongs to me. And then I want you to stay on the other side. See? You stay over there until you're ready for me.

Incisively framing Troy's life and parental obligation in terms of property ("what belongs to me"), Wilson externalizes, with the aid of a baseball bat and a fence, Troy's internalization of the historical conditions under which his character was forged. 
Daisy Wilson's right to win a new washing machine, like her son's right to control his own writing or Hambone's right to his ham or King Hedley II's right to his proper name, thus dramatizes Wilson's character as a characteristic of his characters' claim on the rights usurped under the fabric of human piracy, in the interest of cheap fabrics.

\section{Works Cited}

Wilson, August. Fences. Theatre Communications Group. 2007.

---. Gem of the Ocean. Theatre Communications Group. 2007.

---. Jitney. Theatre Communications Group. 2007.

---. Joe Turner's Come and Gone. Theatre Communications Group. 2007.

---. King Hedley II. Theatre Communications Group. 2007.

---. Ma Rainey's Black Bottom. Theatre Communications Group. 2007.

---. The Piano Lesson. Theatre Communications Group. 2007.

---. Radio Golf. Theatre Communications Group. 2007.

---. Seven Guitars. Theatre Communications Group. 2007.

---. Two Trains Running. Theatre Communications Group. 2007.

\section{Author Bio}

Dr. Alan Nadel, William T. Bryan Chair in American Literature and Culture at the University of Kentucky, is the author of six monographs on post-WWII American literature, including Invisible Criticism: Ralph Ellison and the American Canon (U Iowa P) and The Theatre of August Wilson (Bloomsbury/Methuen). He has also edited of two volumes of essays on August Wilson, May All Your Fences Have Gates and August Wilson: Completing the $20^{\text {th }}$-Century Cycle, both with U Iowa P.

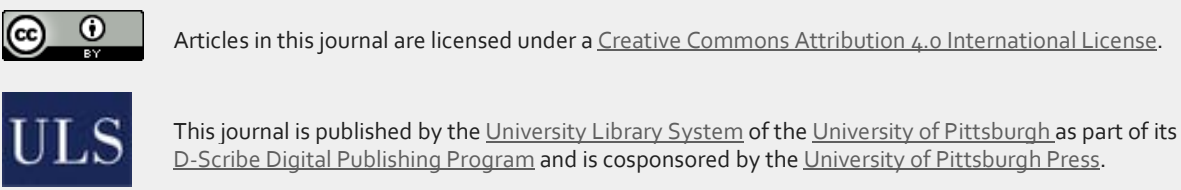

